- FINANSE I PRAWO FINANSOWE.

- Journal of Finance and Financial Law $•$

Wrzesień/September 2017 • vol. 3(15): 81-93

http://dx.doi.org/10.18778/2391-6478.3.15.07

\title{
PODATEK BANKOWY A EFEKTYWNOŚĆ DZIAŁALNOŚCI OPERACYJNEJ BANKÓW KOMERCYJNYCH W POLSCE
}

\author{
Mateusz Muszyński \\ Wydział Finansów i Ubezpieczeń \\ Uniwersytet Ekonomiczny w Katowicach
}

\section{Streszczenie}

Autor przedstawia zagadnienie podatku bankowego wprowadzonego Ustawą z dnia 15 stycznia 2016 r. o podatku od niektórych instytucji finansowych. Celem artykułu jest próba oceny wpływu nowego obciążenia podatkowego na funkcjonowanie wybranych banków komercyjnych notowanych na Giełdzie Papierów Wartościowych w Warszawie oraz skutków jego implementacji dla klientów usług bankowych. W ramach badania empirycznego wykorzystano dane pochodzące ze skonsolidowanych sprawozdań finansowych.

Słowa kluczowe: podatek bankowy, podatek od niektórych instytucji finansowych, sektor bankowy.

JEL Class: G21, H24, H71. 


\section{WPROWADZENIE}

Celem artykułu jest ocena wpływu podatku bankowego na efektywność działalności operacyjnej banków komercyjnych w Polsce oraz skutków jego wprowadzenia dla konsumentów usług bankowych. Przyjęto hipotezy, że wprowadzenie nowego obciążenia podatkowego spowodowało obniżenie podstawowych wskaźników rentowności banków oraz wzrost kosztów ponoszonych przez klientów w związku z korzystaniem z produktów bankowych. Do weryfikacji hipotez wykorzystano analizę zagregowanych danych finansowych.

Artykuł podzielony został na cztery rozdziały, z których dwa pierwsze podejmują problematykę teoretyczną, dwa kolejne oparte są na badaniach empirycznych. Rozdział pierwszy przedstawia rozważania dotyczące głównych koncepcji opodatkowania działalności bankowej oraz kierunki zmian, jakie miały miejsce w Unii Europejskiej po okresie globalnego kryzysu finansowego. Rozdział drugi opisuje rozwiązanie obecnie obowiązujące w Polsce, rozpatrując jego konstrukcję oraz mechanizm funkcjonowania. Część trzecia poświęcona jest sprawdzeniu czy istnieje zależność pomiędzy nowym obciążeniem podatkowym a zarejestrowanym wynikiem $\mathrm{z}$ działalności podstawowej. W ramach rozdziału czwartego przeprowadzono analizę podstawowych wskaźników rentowności przed i po wprowadzeniu podatku bankowego w Polsce. Badanie empiryczne obejmuje dziesięć wybranych banków komercyjnych notowanych na Giełdzie Papierów Wartościowych w Warszawie, wchodzących w skład indeksu WIG Banki, według stanu na koniec 2016 roku. Dane finansowe podlegające analizie obejmują lata 2015-2016 i pochodzą z opublikowanych, skonsolidowanych sprawozdań finansowych.

\section{KONSTRUKCJE MODELOWE PODATKU BANKOWEGO}

Uwarunkowania ekonomiczne ostatniej dekady w wyraźny sposób wpłynęły na obecny sposób funkcjonowania podmiotów rynku finansowego. Szczególne znaczenie zaczęto przypisywać koncepcji stabilności finansowej, wokół której koncentrują się niemal wszystkie działania podejmowane przez władze publiczne oraz regulatorów rynku [Pyka 2010: 202]. Miniony kryzys odsłonił również problem etycznego wymiaru działalności globalnych instytucji finansowych. W konsekwencji konieczne okazało się wprowadzenie nowych rozwiązań w zakresie zarządzania ryzykiem, alokacji kapitału czy wreszcie transparentności decyzji podejmowanych przez podmioty kredytujące [Gospodarowicz i Nosowski 2016: 24]. Wśród grupy nowych instrumentów o charakterze antykryzysowym, duże znaczenie przyznaje się podatkowi bankowemu. 
W ramach szerokiej definicji można przyjąć, że podatek bankowy jest bezzwrotnym świadczeniem publicznoprawnym pobieranym prze państwo od grupy określonych podmiotów finansowych. Za ogólne cele podatku bankowego uznaje się gromadzenie funduszy na wypadek przyszłych kryzysów finansowych, ograniczanie ryzyka podejmowanego przez banki oraz przeciwdziałanie niestabilności na rynkach finansowych. Dodać należy, że świadczenie to nie musi mieć charakteru wyłącznie fiskalnego czy antykryzysowego. $Z$ punktu widzenia rozwiązań przyjętych w krajach unijnych, podatek bankowy pełnić może również funkcję dodatkowego źródła zasilającego budżet państwa. Stosowane modele podatku różnią się ponadto ze względu na podstawę naliczenia (obrót, aktywa, pasywa), podmioty obciążone zobowiązaniem, czas obowiązywania oraz częstotliwość płatności.

Rozwiązanie bazujące na ustanowieniu funduszu restrukturyzacyjnonaprawczego banków, w którym podstawą opodatkowania są pasywa, przyjęły kraje takie jak Szwecja (od 2009 r.) czy Niemcy (od 2011 r.). Banki w Wielkiej Brytanii (od 2011 r.) płacą podatek w zależności od wielkości swoich zobowiązań oraz przeprowadzonych operacji zagranicznych. We Francji (od 2011 r.) podatek bankowy liczony jest od pasywów będących nadwyżką funduszy własnych powyżej $500 \mathrm{mln}$ euro i służy zasilaniu budżetu państwa. W Słowenii (od 2011 r.) podstawą podatku są całkowite aktywa, na Łotwie (od 2011 r.) funkcjonuje specjalna, antykryzysowa opłata bankowa, której podstawą obliczenia są łączne zobowiązania banków, pomniejszone o gwarantowane depozyty [Dec i Masiukiewicz 2013: 67-86]. Przedstawione powyżej przykłady nie są jedynymi wprowadzonymi modelami podatku bankowego, pokazują jednak mnogość stosowanych obecnie rozwiązań ekonomicznych.

\section{PODATEK BANKOWY W POLSCE}

Podatek bankowy w Polsce wprowadzony został Ustawą z dnia 15 stycznia 2016 r. o podatku od niektórych instytucji finansowych. Regulacjami objęte zostały nie tylko banki, lecz również zakłady ubezpieczeń i zakłady reasekuracji, spółdzielcze kasy oszczędnościowo-kredytowe oraz instytucje pożyczkowe. Przepisy dotyczą instytucji mających siedzibę bądź oddział na terenie Rzeczypospolitej Polskiej. Zgodnie z zapisami ustawy, podmioty wyżej wymienione zobowiązane są do zapłaty stawki $0,0366 \%$ wartości podstawy opodatkowania miesięcznie. Sposoby wyliczania podstawy różnią się jednak między sobą. Dla banków podstawę stanowi nadwyżka sumy wartości aktywów, wynikająca z zestawienia obrotów i sald na ostatni dzień miesiąca, ponad kwotę 4 mld zł. Obliczoną w ten sposób podstawę pomniejsza się o wartość fundu- 
szy własnych, ustaloną na ostatni dzień miesiąca oraz o wartość skarbowych papierów wartościowych i aktywów nabytych od Narodowego Banku Polskiego, będących zabezpieczeniem udzielonego kredytu refinansowego. Dla spółdzielczych kas oszczędnościowo-rozliczeniowych nadwyżka liczona jest od kwoty 4 mld zl, z wyłączeniem funduszy własnych oraz wartości skarbowych papierów wartościowych. Kwota wolna od opodatkowania dla zakładów ubezpieczeń i zakładów reasekuracji ustalona została na poziomie $2 \mathrm{mld} \mathrm{zł}$, a dla instytucji pożyczkowych w wysokości $200 \mathrm{mln}$ zł [Ustawa z dnia 15 stycznia 2016 r.]. Według wyliczeń Ministerstwa Finansów wpływy budżetowe z tytułu podatku od niektórych instytucji finansowych za rok 2016 wyniosły ponad 3 mld zł [www1].

Warto jednak zauważyć, że na długo przed rozpoczęciem prac legislacyjnych w środowisku bankowym toczyła się dyskusja dotycząca potencjalnego ryzyka, jakie może nieść ze sobą wprowadzenie podatku bankowego. Nowe rozwiązanie fiskalne traktowane było jako poważne zagrożenie zarówno dla sektora bankowego jak i całego krajowego systemu finansowego. Istotnym punktem dyskursu był argument, że efektywne opodatkowanie sektora bankowego w Polsce należy do najwyższych w Europie. Ponadto, zgodnie z uchwałami Bankowego Funduszu Gwarancyjnego podmioty objęte obowiązkowym system gwarantowania, zobowiązane są już do wnoszenia opłaty ostrożnościowej. Opłata obowiązuje od roku 2013, a podstawę jej naliczania stanowi łączna kwota ekspozycji na ryzyko [Uchwała Rady Bankowego Funduszu Gwarancyjnego...]. Wpłacone środki zasilają tzw. fundusz stabilizacyjny, którego nadrzędnym celem jest wspieranie działań pozwalających na utrzymanie stabilności w systemie finansowym. Koncepcja nowego podatku rodziła jednocześnie strach przed gwałtownym wyhamowaniem akcji kredytowej, mogącym prowadzić do spowolnienia dynamiki wzrostu gospodarczego. Pod znakiem zapytania stawiano również przyszły, oczekiwany poziom rentowności aktywów oraz kapitałów własnych. W sposób szczególny zastanawiano się nad kosztami, jakie w związku z dodatkowymi opłatami banków komercyjnych, będą musieli ponieść ich klienci. Przeprowadzone wcześniej analizy jednoznacznie wskazywały na perspektywę wzrostu opłat i prowizji za czynności bankowe oraz spadku oprocentowania depozytów i wzrostu cen kredytów.

Weryfikacja przeprowadzona w dalszej części artykułu, pozwoli poznać odpowiedź na pytanie, czy argumentacja przeciwników obciążenia fiskalnego w postaci podatku bankowego była słuszna. 


\section{WPŁYW PODATKU BANKOWEGO NA WYNIK Z PODSTAWOWEJ DZIAŁALNOŚCI BANKOWEJ}

Dokonanie oceny wyników finansowych osiągniętych przez banki komercyjne w Polsce w roku 2016 wymaga przedstawienia panujących warunków makroekonomicznych oraz ogólnych tendencji i zmian obserwowanych w samym sektorze bankowym. Rok ubiegły z całą pewnością pozostawał pod znakiem zapytania o perspektywy zachowania stabilności w gospodarce europejskiej. W śród zewnętrznych czynników ryzyka wskazać należy szczególnie decyzję podjętą przez Brytyjczyków o zerwaniu więzi instytucjonalnych z Unią Europejską oraz wyniki grudniowego referendum konstytucyjnego we Włoszech i listopadowych wyborów prezydenckich w Stanach Zjednoczonych. Niepewnością napawały też międzynarodowe niepokoje o charakterze geopolitycznym, jak również prognozy spadku tempa wzrostu gospodarczego największych gospodarek światowych, mogące mieć wpływ na wahania koniunktury w państwach Wspólnoty. Źródeł optymizmu szukać można było w powracającej po dłuższej przerwie w strefie euro inflacji oraz najwyższym od pięciu lat wskaźniku aktywności gospodarczej W sektorze produkcyjnym (54,9 pkt).

Stan polskiej gospodarki charakteryzował się niższą niż zakładano dynamiką wzrostu gospodarczego. Wedle szacunków, Produkt Krajowy Brutto pierwszy raz od trzech lat nie przekroczył poziomu 3\%. Niekorzystne dane odnotowano również w handlu zagranicznym, co wpisało się w ogólnoświatową tendencję wyhamowania wymiany towarowej. Według wyliczeń Międzynarodowego Funduszu Walutowego, wolumen globalnego handlu, pomijając kryzysowy rok 2009, rósł najwolniej od roku 2001. Polski eksport zwiększył się o 2,3\%, co było wynikiem słabszym niż pierwotnie zakładano [Ocena sytuacji $w$ handlu..., 2017: 1]. Za główny czynnik krajowego wzrostu gospodarczego uznać należy popyt wewnętrzny, stymulowany w dużej mierze przez transfery społeczne w ramach programu „Rodzina 500+”. Wzrostowi konsumpcji pomogła także poprawa na rynku pracy oraz ożywienie na rynku mieszkaniowym [Raport o stabilności..., 2016: 18].

Polski sektor bankowy, będący głównym źródłem finansowania gospodarki, pomimo presji zewnętrznych rozwijał się stabilnie. Utrzymujące się środowisko rekordowo niskich stóp procentowych wraz z poprawą nastrojów inwestycyjnych i konsumpcyjnych pozwoliły w okresie od styczna do września 2016 roku na wzrost sumy bilansowej o 69,8 mld złotych $(4.4 \% \mathrm{w}$ odniesieniu rok do ro$\mathrm{ku}$ ). Po stronie aktywów decydujący udział w zmianie miał portfel aktywów dłużnych oraz kredyty, a po stronie pasywów depozyty gospodarstw domowych i sektora budżetowego. W tym samym czasie zarejestrowano także dalsze wzmocnienie bazy kapitałowej. Fundusze własne z poziomu 159,1 mld zł na 
koniec roku 2015 wzrosły o 13,6 mld zł na koniec września 2016 tj. o 8,5\%. Średni łączny współczynnik kapitałowy na koniec roku osiągnął wysokość $17,1 \%$, co również oznaczało poprawę w stosunku do roku poprzedniego [Raport o stabilności..., 2016: 10]. Pozytywnie ocenić należy sytuację banków w obszarze płynności bieżącej. Zdaniem Komisji Nadzoru Finansowego podstawowe wskaźniki płynności pozostawały stabilne, utrzymując się na zadawalających poziomach. Widocznym zjawiskiem na polskim rynku bankowym było podnoszenie efektywności działania poprzez optymalizację zatrudnienia i sieci sprzedaży. W ciągu pierwszych trzech kwartałów roku zlikwidowane zostały 243 placówki a liczba osób zatrudnionych zmniejszyła się o 1,6 tys. Miniony rok był również okresem zmian właścicielskich prowadzonych w ramach polityki konsolidacji krajowego sektora bankowego. Na koniec września, aktywa kontrolowane przez inwestorów krajowych stanowiły już 45,1\% aktywów ogółem [Informacja o sytuacji banków..., 2016: 17]. Warto zauważyć, że szczególną rolę $\mathrm{w}$ ramach tego procesu odgrywały podmioty kontrolowane przez Skarb Państwa. Największym źródłem niepewności dla banków w Polsce zarówno w roku 2016 jak i obecnie były i pozostają zmiany o charakterze regulacyjnym. Ze względu na duży portfel walutowych kredytów hipotecznych, szczególne znaczenie dla banków komercyjnych mieć będzie rozstrzygnięcie w zakresie kredytów denominowanych we frankach szwajcarskich. Za najważniejsze wydarzenie, będące zupełnie nowym wyzwaniem dla polskiego sektora bankowego uznać należy wejście w życie z dniem 01.02.2016 r. ustawy o podatku od niektórych instytucji finansowych.

Jak zauważono we wcześniejszej części artykułu, decyzja o wprowadzeniu podatku bankowego rodziła bardzo poważne wątpliwości. Obawiano się między innymi niekorzystnego wpływu na akcję kredytową, obniżenia poziomu rentowności aktywów i kapitałów własnych oraz bezpośredniego transferu kosztów związanych z podatkiem, na klientów usług bankowych. Głównym źródłem finansowania strat miały stać się podwyższone opłaty oraz prowizje od wykonywanych czynności bankowych.

Aby zweryfikować prawdziwość wyżej wymienionych tez, dokonano porównania wyników z podstawowej działalności bankowej przed i po wprowadzeniu podatku od niektórych instytucji finansowych.

Tabela 1 pokazuje wynik odsetkowy zrealizowany przez dziesięć wybranych banków komercyjnych w roku 2015 (przed wprowadzeniem podatku) oraz 2016 (po wprowadzeniu podatku). Zauważyć można, że w każdym analizowanym przykładzie wystąpiła zmiana pozytywna. Łączny wynik odsetkowy dla przedstawionej grupy zwiększył się o 11,7\%, tj. o 3,002 mld zł. Powodów takiego stanu rzeczy szukać należy po stronie stabilnej akcji kredytowej oraz zmian w polityce depozytowo-kredytowej. Bodźcami stymulującymi rozwój akcji kredytowej były niskie stopy procentowe, poprawa na rynku pracy oraz stabilizacja cen na rynku 
nieruchomości. W zwiększeniu wolumenu kredytów hipotecznych pomógł również rządowy program „Mieszkanie dla Młodych”. Ożywienie zaobserwować można było też dla portfela kredytów konsumpcyjnych i kredytów dla przedsiębiorstw. Obniżenie oprocentowania depozytów, przy jednoczesnym zwiększeniu ceny niektórych kredytów pozwoliło natomiast na podniesienie wypracowanych marż [Informacja o sytuacji banków..., 2016: 14].

Tabela 1. Wynik z tytułu odsetek w tys. zł w roku 2015 i 2016

\begin{tabular}{|l|c|c|c|}
\hline Nazwa Banku & $\begin{array}{c}\text { Wynik z tytułu odsetek } \\
\text { 2015 (przed wprowa- } \\
\text { dzeniem podatku) }\end{array}$ & $\begin{array}{c}\text { Wynik z tytułu odsetek } \\
\text { 2016 (po wprowadze- } \\
\text { niu podatku) }\end{array}$ & Zmiana nominalna \\
\hline ALIOR & 1501013 & 1946049 & 445036 \\
\hline BZWBK & 4309151 & 4770372 & 461221 \\
\hline GETIN & 1195710 & 1316680 & 120970 \\
\hline HANDLOWY & 976600 & 1003570 & 26970 \\
\hline IDEA BANK & 387510 & 624017 & 486300 \\
\hline ING & 2467100 & 2953400 & 321470 \\
\hline MBANK & 2511373 & 2832843 & 140591 \\
\hline MILLENNIUM & 1365247 & 1505838 & 215435 \\
\hline PEKAO & 4166570 & 4382005 & 547800 \\
\hline PKO BP & 6820100 & 7367900 & $\mathbf{3 0 0 2} \mathbf{3 0 0}$ \\
\hline Suma & $\mathbf{2 5 7 0 0 3 7 4}$ & $\mathbf{2 8 ~ 7 0 2 ~ 6 7 4}$ & \\
\hline
\end{tabular}

Źródło: opracowanie własne na podstawie skonsolidowanych sprawozdań finansowych za rok obrotowy 2016.

Tabela 2. Wynik z tytułu opłat i prowizji w tys. zł w roku 2015 i 2016

\begin{tabular}{|l|c|c|c|}
\hline Nazwa Banku & $\begin{array}{c}\text { Wynik z tytułu opłat } \\
\text { i prowizji 2015 } \\
\text { (przed wprowadze- } \\
\text { niem podatku) }\end{array}$ & $\begin{array}{c}\text { Wynik z tytułu opłat } \\
\text { i prowizji 2016 } \\
\text { (po wprowadzeniem } \\
\text { podatku) }\end{array}$ & Zmiana nominalna \\
\hline ALIOR & 331668 & 331134 & -534 \\
\hline BZWBK & 1938100 & 1914720 & -23380 \\
\hline GETIN & 326849 & 126387 & -200462 \\
\hline HANDLOWY & 631350 & 561229 & -70121 \\
\hline IDEA BANK & 363454 & 341892 & -21562 \\
\hline ING & 1017200 & 1064800 & 47600 \\
\hline MBANK & 897176 & 906445 & -15149 \\
\hline MILLENNIUM & 596173 & 581024 & -46562 \\
\hline PEKAO & 2005526 & 1958964 & -157300 \\
\hline PKOBP & 2604600 & 2447300 & $-\mathbf{4 7 8 ~ 2 0 1}$ \\
\hline Suma & $\mathbf{1 0 7 1 2 ~ 0 9 6}$ & $\mathbf{1 0 2 3 3 ~ 8 9 5}$ & \\
\hline
\end{tabular}

Źródło: opracowanie własne na podstawie skonsolidowanych sprawozdań finansowych za rok obrotowy 2016. 
W tabeli 2 przedstawione zostały wyniki banków komercyjnych z tytułu opłat i prowizji. Na podstawie analizy danych można stwierdzić, iż obawy dotyczące przeniesienia kosztów podatku bankowego na klientów nie znalazły potwierdzenia w rzeczywistości. Spośród dziesięciu badanych banków, tylko dwa odnotowały wzrost wyniku z tytułu opłat i prowizji. Zagregowany wynik za rok 2016 obniżył się o 4,5\%, tj. o 478,2 mln zł. Spadek ten spowodowany był w głównej mierze zmniejszeniem przychodów z tytułu sprzedaży produktów ubezpieczeniowych oraz sprzedaży z tytułu obsługi rachunków bankowych i kart płatniczych [Informacja o sytuacji banków..., 2016: 5]. Obniżeniu uległy ponadto przychody $z$ tytułu obsługi funduszy inwestycyjnych i emerytalnych oraz z tytułu działalności maklerskiej, gdzie duże znaczenie miał spadek prowizji z tytułu organizacji emisji obligacji.

\section{OCENA PODSTAWOWYCH WSKAŹNIKÓW EFEKTYWNOŚCI}

Efektywność w dobie gospodarki rynkowej jest jedną z najważniejszych kategorii finansowych, dotyczącą przede wszystkim stopnia realizacji założonego celu. Podobnie jest w działalności bankowej, gdzie zarządzanie efektywnością stało się już odrębnym obszarem zarządzania jednostką.

$\mathrm{W}$ ramach procesu kwantyfikacji efektywności stosuje się cztery grupy wskaźników: rentowności, marży, obciążenia wyniku oraz efektywności zatrudnienia [Capiga 2003: 62]. Są one ważnym instrumentem analitycznym, pozwalającym ocenić czy działalność banku jest efektywna ekonomicznie.

Na potrzeby artykułu, ocenie podlegać będą trzy wybrane miary rentowności: stopa zwrotu z aktywów (ROA), stopa zwrotu z kapitału własnego (ROE) oraz marża odsetkowa.

Stopa zwrotu $\mathrm{z}$ aktywów dla każdego z omawianych banków wyliczona została jako iloraz zysku netto wypracowanego w ciągu danego okresu sprawozdawczego do sumy aktywów na koniec tego okresu. Współczynnik ROA w swej ogólnej charakterystyce informuje o tym ile średnio jednostek pieniężnych zysku netto jest w stanie wygenerować bank ze 100 jednostek ulokowanych w aktywach. Stopa zwrotu z aktywów jest wskaźnikiem względnym. Wartość wskaźnika powinna być jak najwyższa, lecz właściwą ocenę zapewnić może tylko jej naniesienie na szerszy kontekst gospodarczy oraz porównanie z wynikami innych podmiotów działających $\mathrm{w}$ danej branży. Dla badanej grupy banków współczynnik ROA, liczony jako średnia arytmetyczna wzrósł z poziomu $1,08 \%$ do $1,13 \%$, tj. o 0,05 punktu procentowego. Biorąc jednak pod uwagę wyniki osiągane na przestrzeni ostatnich dziesięciu lat (rok 2006: ROA 1,7\%; rok 2007: ROA 1,7\%; rok 2008: ROA 1,6\%) należy stwierdzić, że wartość współczynnika wciąż utrzymuje się na niskim poziomie [Cichy i Puszer 2016: 434]. Wśród 
czynników o charakterze negatywnym wyróżnić należy wzrost kosztów działania (o 13,8\% dla okresu od stycznia do września 2016 w porównaniu do analogicznego okresu roku 2015), będący wynikiem przede wszystkim nowych zobowiązań podatkowych oraz wzrost ujemnego salda odpisów i rezerw [Informacja o sytuacji banków..., 2016: 5]. Można jednak dodać, że średnia stopa zwrotu z aktywów polskiego sektora bankowego w dalszym ciągu pozostaje wyższa niż średnia stopa w pozostałych krajach Unii Europejskiej.

Tabela 3. Wskaźniki stopy zwrotu z aktywów w roku 2015 i 2016

\begin{tabular}{|l|c|c|c|}
\hline \multicolumn{1}{|c|}{ Nazwa Banku } & ROA 2015 & ROA 2016 & $\begin{array}{c}\text { Zmiana nominalna } \\
\text { w punktach } \\
\text { procentowych }\end{array}$ \\
\hline ALIOR & $0,77 \%$ & $1,01 \%$ & 0,24 \\
\hline BZWBK & $1,81 \%$ & $1,59 \%$ & $-0,23$ \\
\hline GETIN & $0,08 \%$ & $-0,06 \%$ & $-0,13$ \\
\hline HANDLOWY & $1,27 \%$ & $1,33 \%$ & 0,07 \\
\hline IDEA BANK & $1,57 \%$ & $2,05 \%$ & 0,48 \\
\hline ING & $1,04 \%$ & $1,07 \%$ & 0,03 \\
\hline MBANK & $1,06 \%$ & $0,91 \%$ & $-0,14$ \\
\hline MILLENNIUM & $0,83 \%$ & $1,02 \%$ & 0,19 \\
\hline PEKAO & $1,36 \%$ & $1,31 \%$ & $-0,05$ \\
\hline PKOBP & $0,98 \%$ & $1,06 \%$ & 0,08 \\
\hline $\begin{array}{l}\text { Średnia arytmetyczna ROA } \\
\text { dla badanej grupy banków }\end{array}$ & $\mathbf{1 , 0 8 \%}$ & $\mathbf{1 , 1 3 \%}$ & $\mathbf{0 , 0 5}$ \\
\hline
\end{tabular}

Źródło: opracowanie własne na podstawie skonsolidowanych sprawozdań finansowych za rok obrotowy 2016.

Drugim analizowanym współczynnikiem rentowności jest stopa zwrotu z kapitału własnego (ROE). Dla każdego z przedstawionych banków wyliczona została jako iloraz zysku netto wypracowanego w ciągu danego okresu sprawozdawczego do sumy kapitałów własnych na koniec tego okresu. Stopa zwrotu z kapitałów własnych tak samo jak stopa zwrotu z aktywów jest wskaźnikiem względnym. Analogicznie zatem wartość wskaźnika powinna być jak najwyższa, nie daje jednak pełnej informacji bez porównania do innych banków i naniesienia na oś czasu. Podkreśla się, iż aby zapewnić właściwy zwrot akcjonariuszom i pozwolić na odtworzenie bazy kapitałowej w ujęciu realnym, współczynnik ROE powinien być o kilka punktów procentowych wyższy od poziomu inflacji [Iwanicz-Drozdowska 2010: 71]. Wobec deflacji $(-0,6 \%)$ jaka miała miejsce w Polsce w roku 2016, warunek ten został w zupełności spełniony [www2]. Tabela 4 prezentuje wyniki skalkulowane dla banków przed i po wprowadzeniu podatku od niektórych instytucji finansowych. Dla badanej grupy 
banków współczynnik ROE, liczony jako średnia arytmetyczna wzrósł z poziomu $9,45 \%$ do $9,83 \%$, tj. o 0,38 punktu procentowego. Ponownie jednak, konieczne jest odwołanie się do lat wcześniejszych. Obserwacja zapisów notowanych w latach: 2006: ROE 22,5\%; 2007: ROE 22,5\%; 2008: ROE 15,7\% pozwala zauważyć, że z perspektywy czasu obecne wartości znajdują się na niskim poziomie. Wysoka rentowność kapitałów własnych w tamtych latach była wynikiem relatywnie niskich kapitałów własnych. Od roku 2010 można mówić o stabilizacji wskaźnika. Taki stan rzeczy wyjaśnić można szybszym wzrostem sumy bilansowej, świadczącym o rozwoju sektora bankowego w Polsce oraz wzrostem kapitałów własnych, będącym efektem wprowadzanych regulacji ostrożnościowych.

Tabela 4. Wskaźniki stopy zwrotu z kapitału własnego w roku 2015 i 2016

\begin{tabular}{|l|r|r|c|}
\hline \multicolumn{1}{|c|}{ Nazwa Banku } & ROE 2015 & ROE 2016 & $\begin{array}{c}\text { Zmiana nominalna } \\
\text { w punktach } \\
\text { procentowych }\end{array}$ \\
\hline ALIOR & $8,79 \%$ & $9,96 \%$ & 1,17 \\
\hline BZWBK & $13,07 \%$ & $12,05 \%$ & $-1,02$ \\
\hline GETIN & $1,05 \%$ & $-0,76 \%$ & $-1,81$ \\
\hline HANDLOWY & $9,14 \%$ & $8,86 \%$ & $-0,28$ \\
\hline IDEA BANK & $14,49 \%$ & $17,95 \%$ & 3,46 \\
\hline INGBSK & $10,55 \%$ & $11,96 \%$ & 1,41 \\
\hline MBANK & $10,62 \%$ & $9,36 \%$ & $-1,26$ \\
\hline MILLENNIUM & $8,48 \%$ & $10,10 \%$ & 1,62 \\
\hline PEKAO & $9,79 \%$ & $9,95 \%$ & 0,16 \\
\hline PKOBP & $8,51 \%$ & $8,86 \%$ & 0,35 \\
\hline $\begin{array}{l}\text { Średnia arytmetyczna ROE } \\
\text { dla badanej grupy banków }\end{array}$ & $\mathbf{9 , 4 5 \%}$ & $\mathbf{9 , 8 3 \%}$ & $\mathbf{0 , 3 8}$ \\
\hline
\end{tabular}

Źródło: opracowanie własne na podstawie skonsolidowanych sprawozdań finansowych za rok obrotowy 2016.

Ostatnią badaną miarą rentowności jest marża odsetkowa, będąca ilorazem wyniku z tytułu odsetek na koniec roku sprawozdawczego do sumy aktywów na koniec tego okresu. Marżę odsetkową traktować można jako nadwyżkę oprocentowania aktywów nad oprocentowaniem pasywów [Iwanicz-Drozdowska 2010: 74]. Tabela 5 pokazuje, że wskaźnik marży odsetkowej wzrósł prawie dla wszystkich banków z badanej populacji. Średnia marża odsetkowa zwiększyła się z poziomu $2,40 \%$ do $2,55 \%$. Wzrost spowodowany był tym, że w badanym okresie banki potrafily dobrze wykorzystać politykę niskich stóp procentowych, obniżając oprocentowanie depozytów i podnosząc je dla niektórych produktów kredytowych. $\mathrm{Na}$ wzrost marż oddziaływał również rosnący wolumen sprzedaży kredytów. 
Tabela 5. Wskaźniki marży odsetkowej w roku 2015 i 2016

\begin{tabular}{|l|c|c|c|}
\hline \multicolumn{1}{|c|}{ Nazwa Banku } & $\begin{array}{c}\text { Marża odsetkowa } \\
2015\end{array}$ & $\begin{array}{c}\text { Marża odsetkowa } \\
2016\end{array}$ & $\begin{array}{c}\text { Zmiana nominalna } \\
\text { w punktach } \\
\text { procentowych }\end{array}$ \\
\hline ALIOR & $3,75 \%$ & $3,18 \%$ & $-0,57$ \\
\hline BZWBK & $3,08 \%$ & $3,18 \%$ & 0,09 \\
\hline GETIN & $1,69 \%$ & $1,98 \%$ & 0,29 \\
\hline HANDLOWY & $1,97 \%$ & $2,22 \%$ & 0,25 \\
\hline IDEA BANK & $2,06 \%$ & $2,90 \%$ & 0,84 \\
\hline ING & $2,27 \%$ & $2,51 \%$ & 0,25 \\
\hline MBANK & $2,03 \%$ & $2,12 \%$ & 0,08 \\
\hline MILLENNIUM & $2,06 \%$ & $2,19 \%$ & 0,13 \\
\hline PEKAO & $2,47 \%$ & $2,52 \%$ & 0,05 \\
\hline PKOBP & $2,60 \%$ & $2,70 \%$ & 0,10 \\
\hline $\begin{array}{l}\text { Średnia arytmetyczna } \\
\text { marża odsetkowa dla } \\
\text { badanej grupy banków }\end{array}$ & $\mathbf{2 , 4 0 \%}$ & $\mathbf{2 , 5 5 \%}$ & $\mathbf{0 , 1 5}$ \\
\hline
\end{tabular}

Źródło: opracowanie własne na podstawie skonsolidowanych sprawozdań finansowych za rok obrotowy 2016.

\section{PODSUMOWANIE}

Podatek bankowy obowiązujący w Polsce od lutego 2016 jest nowym obciążeniem fiskalnym o charakterze redystrybucyjnym. W ramach artykułu podjęto próbę oceny skutków jego wprowadzenia dla efektywności banków komercyjnych oraz kosztów, na jakie narażeni zostali klienci usług bankowych. Analiza obejmowała wyniki banków zrealizowane w dwóch okresach sprawozdawczych, przed i po wprowadzeniu podatku bankowego. Przeprowadzone badanie empiryczne, oparte na danych pochodzących z grupowych sprawozdań finansowych wybranych banków giełdowych, pozwala na sformułowanie następujących wniosków. Nie wszystkie początkowe obawy przed implementacją podatku, znalazły potwierdzenie $\mathrm{w}$ rzeczywistości. W rozważanym odcinku czasu, obserwować można było wzrost dynamiki akcji kredytowej. W kierunku wzrostu sprzedaży produktów kredytowych oddziaływały przede wszystkim wysoki popyt wewnętrzny oraz niskie stopy procentowe. Rentowność banków wzrosła nieznacznie, dalej utrzymując się na niskim z retrospektywnego punktu widzenia poziomie. Wynik z tytułu opłat i prowizji w roku 2016, zmniejszył się w odniesieniu do roku poprzedniego. Wzrost odnotowano natomiast dla wyniku z tytułu odsetek, co świadczy o zwiększeniu średniej marzy odsetkowej. Wykorzystując otoczenie niskich stóp procentowych, banki obniżyły oprocentowanie depozytów przy jednoczesnym zwiększeniu oprocentowania niektórych kredytów. 
Za względu na krótki okres obowiązywania podatku bankowego w Polsce, ryzyko z nim związane nie zostało jeszcze prawdopodobnie w pełni zmaterializowane. Nie można zatem wykluczyć, że w dalszej perspektywie czasu sytuacja w ocenianych obszarach ulegnie zmianie, a banki poprzez agresywną politykę w zakresie marż, opłat i prowizji będą próbowały zrekompensować koszty podatku bankowego.

\section{BIBLIOGRAFIA}

Capiga M., 2003, Ocena działalności placówki operacyjnej banku: dylematy metodologiczne i praktyczne, Prace naukowe Akademii Ekonomicznej im. Karola Adamieckiego w Katowicach, Katowice.

Cichy A., Puszer B., 2016, Sektory bankowe w Unii Europejskiej, Wydawnictwo Uniwersytetu Ekonomicznego w Katowicach, Katowice.

Dec P., Masiukiewicz P., 2013, Podatek bankowy, Wydawnictwo C.H. Beck, Warszawa.

Gospodarowicz A., Notowski A., 2016, Zarządzanie instytucjami kredytowymi, Wydawnictwo C.H. Beck, Warszawa.

Informacja o sytuacji banków w okresie I-IX 2016 r., 2016, Urząd Komisji Nadzoru Finansowego, 2016, Warszawa.

Iwonicz-Drozdowska M., 2010, Zarzadzanie finansowe bankiem, Polskie Wydawnictwo Ekonomiczne, Warszawa

Ocena sytuacji w handlu zagranicznym w 2016 roku, 2017, Ministerstwo Rozwoju: Departament Strategii Rozwoju, Warszawa.

Pyka I., 2010, Bank centralny na współczesnym rynku pieniężnym: dyscyplina regulacyjna, skuteczność, instrumenty, Wydawnictwo C.H. Beck, Warszawa.

Raport Grupy Kapitałowej Banku Millennium S.A. za okres 12 miesięcy zakończony 31 grudnia $2016 r$.

Raport o stabilności systemu finansowego - grudzień 2016, 2016, Narodowy Bank Polski: Departament Stabilności Finansowej, 2016, Warszawa.

Roczne skonsolidowane sprawozdanie finansowe Grupy Kapitałowej Banku Handlowego w Warszawie S.A. za rok obrotowy kończacy się 31 grudnia 2016 roku.

Roczne skonsolidowane sprawozdanie finansowe Grupy Kapitałowej ING Banku Śląskiego S.A. za 2016 rok.

Skonsolidowane sprawozdanie finansowe Grupy Kapitałowej Alior Banku Spótki Akcyjnej za rok zakończony 31 grudnia 2016.

Skonsolidowane sprawozdanie finansowe Grupy Kapitałowej Banku Zachodniego WBK S.A. za 2016 rok.

Skonsolidowane sprawozdanie finansowe Grupy Kapitatowej Getin Noble Banku S.A. za rok zakończony dnia 31 grudnia 2016.

Skonsolidowane sprawozdanie finansowe Grupy Kapitałowej Idea Banku S.A. za okres 12 miesięcy zakończony dnia 31.12.2016.

Skonsolidowane sprawozdanie finansowe Grupy Kapitałowej mBanku S.A. wedtug Międzynarodowych Standardów Sprawozdawczości Finansowej za 2016 rok.

Skonsolidowane sprawozdanie finansowe Grupy Kapitatowej Banku Pekao S.A. za rok zakończony dnia 31 grudnia 2016. 
Skonsolidowane sprawozdanie finansowe Grupy Kapitatowej PKO Banku Polskiego S.A. za rok zakończony dnia 31 grudnia 2016 roku.

Uchwała Rady Bankowego Funduszu Gwarancyjnego z 20 września 2016 r., nr 49/2016.

Ustawa z dnia 15 stycznia 2016 r. o podatku od niektórych instytucji finansowych, Dz.U. 2016, poz. 68.

[www1] http://www.mf.gov.pl/ministerstwo-finansow/wiadomosci/komunikaty/-/asset_publisher/ $6 \mathrm{Wwm} /$ content/szacunkowe-wykonanie-budzetu-panstwa-w-okresie-styczen-listopad-2016-r.

[www2] http://stat.gov.pl/obszary-tematyczne/ceny-handel/wskazniki-cen/wskazniki-cen-towarow -i-uslug-konsumpcyjnych-pot-inflacja-/roczne-wskazniki-cen-towarow-i-uslug-konsumpcyjnychw-latach-1950-2014/\#.

\title{
THE INFLUENCE OF BANK TAX ON SELECTED BANKS LISTED ON THE WARSAW STOCK EXCHANGE
}

\begin{abstract}
The article deals with the bank tax which was implemented in Poland in Fabruary 2016. The main role of the paper is to examine what is the impact of the new tax on the group of banks listed on the Warsaw Stock Exchange. The special emphasis in the analysis has been put on profitability and efficiency. Furthermore, the author tries to verify to what extend the tax burden was shared by the clients of the financial services. Data used in the empirical research come from the approved, consolidated financial statements.
\end{abstract}

Keywords: bank tax, bank levy, banking sector, profitability, Warsaw Stock Exchange.

Przyjęto/Accepted: 20.05.2017

Opublikowano/Published: 30.09.2017 